\title{
Off/On-Screen Representation Of Women in Kurdish Television Advertisements
}

\author{
Shaima Waseem Sadiq \\ Coventry University
}

\author{
Kovan Hussein saado \\ University of Sulaimani
}

\section{Article Info}

Received: October , 2020

Revised:November,2020

Accepted: December ,2020

\section{Keywords}

ads, women, Kurdish, feminism, postfeminism, qualitative methodology, questionnaire.

\section{Corresponding Author} kovan.saado@univsul.edu.iq

\section{Abstract}

The present study attempts to examine the 'on/off screen portrayal' of women in mass media in particular in Kurdish television advertisements. As gender representation, stereotyping and objectification of women in Kurdish television advertisements have received little attention in academic filed. This research focuses on the issues of mis/representation of women in Kurdish Media advertisements. It also implements feminism and postfeminism literature on contemporary Kurdish advertisements to see if they are applicable. Therefore, this research, critically explores the role of women in advertisement in Kurdistan region media to understand the impact of advertisement on the changing role of women in the society.

We employ qualitative methodology of questionnaire to collect the data from ads 'directors'. 6 Kurdish advertisements selected in accordance of three themes, 2 videos for each theme. And for the questionnaire 8 Kurdish advertisement directors. In this regard, the research implements more than one tool to achieve triangulation to enhance validity and reliability of this study. 


\section{1-Introduction}

This chapter starts with an overview of the background of the study, follows by the background of advertisement in Kurdistan. Thereafter, it will shed light on the statement of the problems and the context of this study. From here on the rationale behind designating the topic, followed by the aims of the study will be highlighted. The final part will explain the value of the study.

\section{2- The background of this study}

Advertising is becoming more and more important in our daily lives and it is a tool that companies use in order to gain the trust of the consumers so they would buy those products. With the technological advancements and the spread of social media platforms, people are relying more on advertisements to make their purchase decision. Advertisement is one of the effective ways that companies and even social enterprises use to deliver their messages. So, advertisements are created by company's producers in order to attract most viewers to the product and the directors would try their best in order to make the ads as appealing as possible. In creating advertisements in which women are used as main characters, or even secondary characters, it is essential to observe which role the women are assigned to (Nagi 2014: p.76). As it is stated, advertisers study their audience, what they like what they dislike and what the most needed products are, and things related to each gender occupy most of their investigative work. In the advertising world of the near past, like the 1970s, women were depicted as weak and only in roles where they were shown as domestic and kind. For instance, in Christmas ads women were shown the happiest when the husband bought sewing machine for her which highlights the domestic nature of the women.

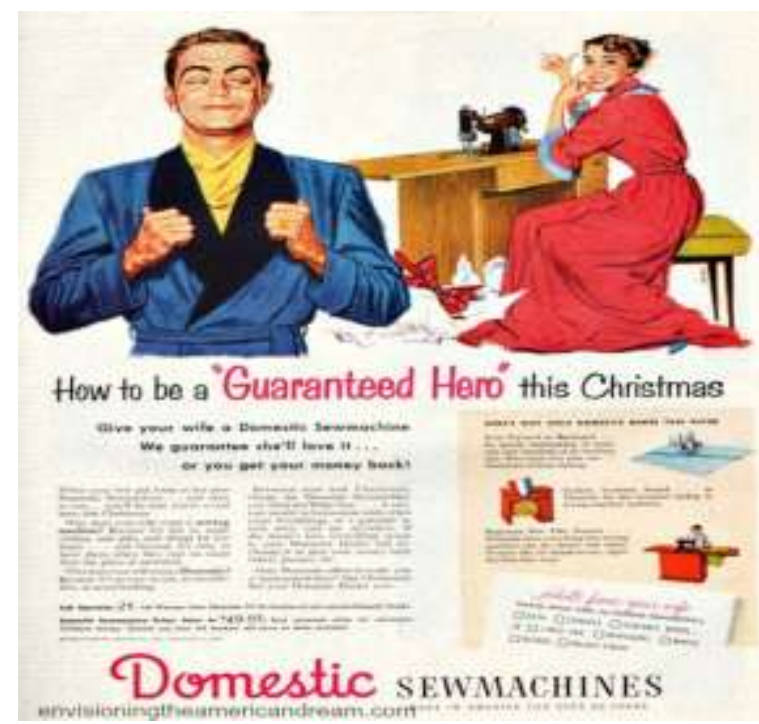

This has shifted in recent years. Through the use of powerful and famous actresses and female TV personalities the depiction women has changed to one of empowerment and fearlessness (Malson et al., 2010). Whenever one sees Beyonce or Jennifer Lopez in an ad one does not think about a submissive woman, instead one thinks about an independent woman who does what she desires regardless of what others think about her. Therefore, through assigning women with different roles one can assume the subtle message of the particular advertisement that it wants to convey. As an opposite example, when we see a woman trying to use detergent to wash the dishes, the hidden message we receive is one of a submissive and a housewife woman. The analysis done by Belkaoui and Belkaoui (1976) 
on some major magazines from the 1950s showed that women are represented as secondary characters and the women are assigned mostly as housewives (as cited in Nagi 2014). Tsichla and Zotos (2014: p.26) claim that the ads in which they examined the roles of women have shown that women are stereotyped and depicted in traditional roles which conforms to the norms of the societies. Stereotyping women means giving women roles that are seen by the society proper to them like Vantomme, Geuens, and Dewitte (2005: p.4) argue"[stereotyping is to] attribute independence to men and affiliation to women "Whereas nowadays, the role of women has dramatically changed. Women are not a secondary character any more.

\subsection{Background of Advertisement in Kurdistan}

Research done exploring this area, role of women in advertisement, has been carried out in the west and those papers are not compatible with the Kurdish culture as there are vast differences between a middle eastern society and a western society. For instance, women and men cannot express their affection for each other publicly in Kurdistan, which is a very normal thing to do in a western society (Robson 1996). Robson states that Kurdish women are considered to be a part in the house of their husbands and even they themselves may see their situation like that (1996: p.16). The Kurdish society is not an open society. The Kurdish society is still a retrogressive one.
Women are still mostly perceived as housewives. However, because of globalization and the massive influences of the west the Kurdish society is progressing and this may or may not affect the role of women. Hence, the present study tries to evaluate the role of women in the society through their representations in Kurdish advertisements.

The research examines many Kurdish advertisements to see whether they stereotype women or not in their advertisements. Also, the ideas and opinions of Kurdish media and advertisements academics are taken in order to know if marketers and media practitioners are aware of stereotyping women intentionally, or if advertisements did actually show women in stereotypical roles. The present study also explores the mentality of the advertising directors and advertisement academics towards the roles of women in the media and advertisement field.

\subsection{The statement of the problems}

Making advertisements and employing women in them has become highly significant in the recent years. As a result of the increasing variety of media channels through which advertisements are aired, they reach larger audiences. Therefore advertisement can have bigger impact the way role of women is perceived in the society. There are debates and disagreements on the roles of women and their rights in advertisements as it would be shown in the interviews conducted in the present study with Kurdish university 
professors. The ideas and opinions vary as one side would say that the roles of women are progressing and one can see their prominence in the field of advertisement; and the other side completely disagrees as they argue no such prominence can be observed. Directors, therefore, have a difficult job in assigning the roles for women. They would be able to change the whole perspective of the audience about women in the society through their work. This research will be carried out as a result of the absence of the research concerning the role of women in Kurdish advertisements.

\subsection{Context for the research}

In order to collect an effective sample of the stakeholders of advertisement industry in Kurdistan, Kurdish media academicians have participated in the research. Through conceptual framework the research utilizes the areas of the production work in Kurdistan, advertisement in Kurdistan, and the range of women participation in ads productions. 8 advertisement directors have participated through answering questionnaires. The questionnaire has covered the areas of the production work in Kurdistan, advertisement in Kurdistan, the differences between men and women in advertisements and the basis for how the roles are assigned to men and women. These academics are among the most prominent scholars in their respected fields and both are $\mathrm{PhD}$ holders and university professors. The reason these academics has been selected is to have evaluate female portrayal in ads and their roles in the media because their academic oeuvres. The researchers attempt to have more academicians but due to the major inadequacy only several of them have been selected.

\subsection{The rationale for this study}

Through observing a large number of the advertisements produced in Kurdistan, It can be seen that women are shown either as housewives, objectifications or hypersexualized with a very compelling voice and posture. There has been a surge in the making of advertisements in Kurdistan with many agencies coming to the scene that are specialized in admaking. Before these specialized companies we could only see Persian, Arabic, or Turkish advertisements being played for the product that those countries produced themselves. Many advertisements in Kurdistan stereotype women; for instance they show women as housewives, caretakers, sensual, and kind. However, some use famous female personalities and show them as powerful individuals. As Malson et al (2010) state that through the use of powerful and famous actresses and female TV personalities the depiction of women has changed to one of empowerment and fearlessness. Thus, this study hopes to gain a new insight into the role of women in Kurdish advertisement and how they would reflect the Kurdish society.

\subsection{The aims of this study}

Based on the aims set for it, the research endeavors to answer the following questions: 
1. What are the roles of women in advertisements in general and in the Kurdistan Region in particular?

2. What is postfeminism and how are the postfeminist discourses apparent (or not) in Kurdistan advertisements?

3. Does one see any progression in the depiction of women in the Kurdistan advertisements?

4. what are the on/off screen women's roles in advertisements

\subsection{The value of this study}

This research will hopefully and potentially be valuable for:

1. The Media Departments in Kurdistan universities

2. Advertisers who may want to be more sensible in assigning roles to women

3. Researchers in the field of Media and advertisement has been an up-to-date studies

4. Giving foreign observers up-to-date insight into the field of advertisement in Kurdistan.

5. Women themselves who try to enter the field as the present study provides them with insight into the way of thinking of advertisement.

\section{Chapter Two: Literature Review}

According to Murray and Hughes (2008) a literature review should be concerned with the essential background knowledge related to the researched project in order to unearth the influence and deficiency of previous studies (p.145-148). This means that the literature review makes the researchers aware about what is going to be done by giving them different view through previous studies (Murray \&
Hughes 2008: 145-148). In this regard, this chapter is designed to critically evaluate the literature which is related to the current study.

\subsubsection{Feminism as a Movement against}

\section{Patriarchy}

Understanding feminism can be complicated as there are so many definitions for it. The definitions vary from one culture to the other. For instance, in Kurdistan the word Feminism does not have a good connotation; most of them consider it as misandry or ' philogyny'. This bad connotation is not something exclusive to Kurdistan; it has some global aspect to it "To be pro-women is often associated with being antimen. The link between feminism, whereas 'woman' is already in the word itself, as something that is anti-men is often made" (Trap 2017: 18). This feminism and anti-men connection is often made as men are afraid of women arising to have their own voices in the society. This way of thinking is related to the deep roots of patriarchy which dominates most of the Kurdish society "...Kurds are inhabitants of what is sometimes called the patriarchal belt; ...women are expected to limit themselves to tasks that are considered appropriate for them" (Çağlayan 2012: 2). What is meant by the patriarchal belt is the countries around Kurdistan, such as Iran, Iraq, Turkey and Syria . Kurdistan itself is patriarchal societies; the belt may be a metaphor for the tight grip of men on power in those countries. Women are expected to do certain things in these patriarchal societies like household chores and caretaking. Patriarchy 
in a literal sense means the rule of the father. Walby (1989) defines patriarchy as "a system of social structures and practices in which men dominate, oppress and exploit women". Based on the definition Kurdistan can be considered a patriarchal society; in Kurdistan men dominate power and all the important sectors in the society. In Southern Kurdistan the political parties who are gradually the decision-makers are all run by men; we have only one party, namely the Patriotic Union of Kurdistan, has a female leader. This point is significant as by knowing this one can comprehend how androcentrism is Kurdish society . One aspect that may tell that Kurdistan is patriarchal is how the Kurdish people revere and idolize the powerful male figures who fought for the Kurdish rights. This idolization of male figures would naturally diminish whatever women do, as Mies (1986: 199) as cited in (Yeşil 2003) argues that "the role of women...is obscured by idealizing the founding fathers..." (p. 26).

Under patriarchy the right of women's education is a top priority for Feminists as education makes women aware of their own values "...restricting women's right to education denies them access to information about their rights, especially their right to choose how they live" (Yeşil 2003: 32). Thus women cannot be free from the restrictions of patriarchy unless women get their right of education. Through education illiteracy of women can be demolished and women can gain confidence to demand what is right for them. So because of the lack of education that women have in patriarchal societies even women themselves, consciously or unconsciously, are submitted to the patriarchal rules. Women are directed to help further implementing the rules of patriarchy "Women themselves are taught, in the process of being socialized, to internalize the reigning patriarchal ideology" (Abrams \& Harpham 2011: 89, 91). Patriarchal ideology means prioritizing masculinity over femininity and giving advantages to males in all sectors of life.

Based on the previous understanding of how patriarchy dominates societies, feminism as a movement arose to go against the norms and to help individuals to discover themselves outside the rules put forth by patriarchy "feminism has been the most important source of self-discovery and political change for us, slowly transforming our understandings of ourselves" (Murphy 2004: 82).It can be said that feminism is a movement which demands equal rights for women in every aspect of life; they reject sexism, patriarchal oppression and all the discriminations that come with them, and they strive for women to have the right of choice (Hooks 2000: 1). As it was said above, having the right of choice is important for women as it allows them to take back control of their bodies and be independent individuals as they would not wait on men to make their choices for them.

\subsubsection{Historical Context}

Feminism is not static as it changes according to the changes of the needs and situations of women. Bryson (2016) argues that because of 
women's exclusion from most or any public debate there are few records of women asking for their own rights and we have no access to what have been said about those rights in the ancient times (p.5). According to Habib (2006) Christine de Pisan can be considered one of the most influential women's rights activists in the 1300 s and 1400s. She became a widow in a very young age and as per the rules at that time she couldn't inherit anything. She was left to struggle in life with three kids. However, she didn't accept her situation and started to get a living out of writing. Through her works she tried to show how misogyny affects the way women are viewed in the public sphere (p.220).

In order to clarify the changes in the feminist interests in a more systematic way experts have divided feminism into three metaphorical waves; the first wave of feminism started in the late 19th century; the second wave of feminism which was between 1960s and 1980; and the third wave of feminism which started in the early 1990s (Bisong \& Ekanem 2014: 34). However, these metaphorical waves are not perfect representations of the history of feminism as they could lead readers to the false belief that feminist movements and female voices were nonexistent outside these waves, which is not true (Freedman: 2001: 4). In the late nineteenth century and early twentieth century women's movement stepped forward from theory to practice. In the United States of America and getting inspiration from the feminists' efforts in Europe feminists rose to ask for their basic rights of voting, owning properties, and entering any kind of contracts as women were seen as men-subordinates who can only have a voice through their fathers, brothers and husbands (Freedman 2001: 4). It was not an easy task for those brave women and suffragists who stood up against the system and asked for women's rights as they were scorned by the society and they were depicted as monsters who wear male clothes and smoke cigars and they want to dominate the society and fight men off their thrones (Paglia 2008: 7). Women were seen like monsters who smoke and wear men's clothes as those women refused the Angel in the House image that was imposed on them by the society. The image of the Angel in the House is the typical Victorian woman who wears modest clothing, takes care of the house and obeys the patriarch of the house (Snodgrass 2013). So when a lady smokes and wears clothes opposite to what is specified for her shows a strong sign of rebellion against the norms of the society. Paglia (2008) states that it was because of this wave of feminists that women gained the right to vote in the United States. These brave women tirelessly went into the streets and gave passionate speeches about how women should have the right to vote just as their male counterparts (p.7). One should not shorten the importance of this wave in only getting women the right to vote as they have done much more as Freedman (2001) asserts. Freedman says that this wave of feminists was after equality in general with suffrage being in the center of their 
demands (pp. 4, 5). Suffrage right means the right to participate in voting for whomever one desires to vote for (Miller 2008). The first wave feminist movement relied heavily on single women to achieve their goals as these women were brave enough to step up for their rights. However, this movement was too white as women of color were no were to be seen so the rights of those colored women were not high on the list of priorities (Moran 2004).

Just like the first wave feminists, the second wave feminists were white and middle class (Moran 2004). Still in this wave women of color had no position. The second wave feminists were different from the first wave feminists in that they ignored the single women who were the bulk of the first wave feminism. second wave feminists were mostly married and this excluded even lesbians were excluded and these discriminations were huge shortcomings of this wave (p.5)

The previously discussed women's rights movements and feminist waves happening in the western countries like the United States of America, England, and France because their history are well-documented and any researcher could acquire as much resources as one needs. In the Middle East in general and Kurdistan in particular, however, resources are scarce documenting women's rights movements. One major reason for the scarcity of records, as Bruinessen (2001: 1) asserts, is because "...of an anti-female bias in historiography...". So according to Bruinessen (2001) the achievements of women or their important roles are under-reported because those who have written history books were males who were a part of the patriarchal system as the Kurdish society is still patriarchal and "it has been for all of its known history" (p.1). Some of the feminist ideas could be applied to Kurdistan, too. In Kurdistan as Dr. Salam (2018) suggests that we have centers that investigates the problems arising from the gender issues. Women in Kurdistan can get job opportunities; although the women may not be able to acquire the highest positions. Although the third wave feminists claim to be more inclusive than the previous waves and they claim to give the younger girls a voice, they feel somewhat enraged if someone claimed the word 'third wave' (Dean 2009). This feeling of ownership toward the word, shows how the third wave feminists feel entitled to some rights which should not be given to others (p.346).

\subsection{Postfeminism}

Adriaens and Van Bauwel (2014: 6) argue that postfeminism is "...a discourse that gives women the opportunity to be feminine, attractive, and a feminist at the same time". So according to Adriaens and Van Bauwel (2014) women being beautiful and showing their beauty should be encouraged as it is a kind of empowerment for women. Women's body is not taboo anymore. The "Independence, individual choice, (sexual) pleasure, consumer culture, fashion, hybridism, humor... are the fundaments of this new feminism" (p.6). Postfeminism is 
inscribed in popular culture of TV series and movies and one can see how the celebration of women's individuality and choices are shown. Postfeminism refuses some of the demands of the previous waves of feminism. For instance, feminists have tried for so long to show the bad sides of women being housewives and how it is a way for subjugating women. Poovey (1984: vii) as cited in (Walker 2015: 2) asserts that in 1792 Wollstonecraft criticizes women's domestic labour and how this labour was playing a huge role in the imprisonment of women in their houses and depriving them from any public roles. However, as Walker (2015) argues, postfeminists try "...rebranding of domestic labouras a site of pleasure and freedom articulated through means of popular culture, in filmand TV programmes..." (p.5). Lancioni (135-36) as cited in (Adriaens \& Van Bauwel 2014) state that when a woman chooses to be a housewife it is completely up to her and should not be criticized for her decision and she should not be considered any lesser than a woman who chooses a career (p.5).

According to Gill (2007) as cited in (Sun 2017) postfeminist discourses include:

(1) Femininity is increasingly portrayed as a bodily property rather than a socially constructed one; (2) women sometimes are represented in a sexual subjectification rather than objectification way; (3) women are depicted as individual, autonomous, empowered, and self-surveilling subjects serving their own wills and desires; (4)there is a resurgence of ideas of natural gender difference, which reeroticizes gender relations; and (5) consumerism is celebrated as a woman's right to choose (p.2628).

Femininity is a set of different adjectives used to label women "... as nurturing, emotional, passive and attractive" (Lewis 2014). So according to the understanding of the second wave movement Femininity was something to be far from. Also, it is fine if women be shown in a sexual way or women show their sexuality as it is not about objectification but rather their own choice and subjectification. However, Gill criticizes this subjectification of women as she argues that this subjectification of women is even more exploitative of women than the objectification of women. She says that this subjectification of women is "...a shift from an external, male judging gaze to a self policing narcissistic gaze" and that "Girls and women are invited to become a particular kind of self...on condition that it is used to construct oneself as a subject closely resembling the heterosexual male fantasy that is found in pornography" (2007). Another postfeminist discourse is that one should not try and say there are no differences between men and women as there are natural gender differences, like interest differences, and those differences are normal. Furthermore, women shown as liking to shop should not be considered as insulting to women as it is women's right to choose shopping and be a consumer of luxurious shoes and dresses and whatever else she likes (p.2628). So this notion 
of postfeminism that women should dress lavishly and live for themselves fail its point as Gill (2007) argues that in this process some standards would be created that would againg marginalize women. Women shown on TV seem happy, powerful, and fit which conveys the message that women should be like that and this is no different from the dress codes that were imposed on women in the past.

\subsection{Representation}

Representation, as Hall (1997: 15) argues, is "...an essential part of the process by which meaning is produced and exchanged between members of a culture". So based on this argument by Hall one can convey a message to the surrounding by going through the process of representation. Hall (1997) further explains that this process of representation comes into being by using language, signs, and images and these stand for something that one wishes to represent (p.15). Then Hall gives examples of representation and how it comes to stand for or symbolize something:

...the cross simply consists of two wooden planks nailed together; but in the context of Christian belief and teaching, it takes on, symbolizes or comes to stand for a wider set of meanings about the crucifixion of the Son of God, and this is a concept we can put into words and pictures (1997: p.6)

So the cross in itself is just a wood and some nails, it is people who give meanings and decide what that wood represents or not. For instance, in Kurdistan there is a rock in a small town near

Sulaimania called "Barda Qaraman" or could be translated as "The Hero's Rock". The rock is very well taken care of and it is surrounded by flowers. The rock is thought to be the last place that Malik Mahmud, the first king of Kurdistan, has rested on as he sustained injury in his fight against the British Empire. So the rock is nothing without the thing that it represents and when it represents something it gets a whole new meaning and importance.

Many times when something is represented there is some agenda at play. As Kidd (2015) explains "When people create representations of the world there are agendas at play, and particular sets of ideas, values, attitudes and identities assumed and normalized" (p.3). Hence, one must carefully examine what one sees represented in front of one as sometimes a representation seems innocent yet it is not. For instance, in a feministic perspective, when one sees women shown as caretakers it is with the agenda to normalize caretaking for women.

Regarding the representation of women there has been a shift throughout the years. Gill (2007) argues that the femininity of women before meant "caring or nurturing or motherhood" and these characteristics were central to what femininity meant. However, nowadays women having attractive bodies, always taking care of their bodies and spending money constantly on products, is the central of femininity (p.6).

\subsection{Advertising}


Advertising is a tool of marketing (Nagi 2014). Nagi defines marketing as "The process of planning and executing the conception, pricing, promotion and distribution of ideas, goods and services to create exchanges that satisfy individual and organizational objectives" (2014: 75). So marketing is a process of finding a market for whatever product that one has and this marketing should be catered to the taste of the one or the ones interested in the product. As Ali and Shahwar (2011) assert that adverting is a way to communicate with customers and convey to them that the product or the service you have is worthy of their attention and they should spend money on it (p.152).

\subsubsection{Representation of Women in}

\section{Advertising}

Kang (2002) as cited in (Nagi 2014) states that women are more frequently used in advertisements and the use of female models is on the rise. But this use of women in advertisements is not always for products and services that are related to women. Also Katharina (2004) as cited in (Nagi 2014) is skeptical too of the use of women in advertisements as she claims women are being used as sex objects and as baits for catching the attention of viewers. We can see what these respected writers talk about as sometimes you see an advertisement which is about a chocolate bar and you see a woman posing almost nude just to eat it and touching the bar and themselves with a feminine touch.
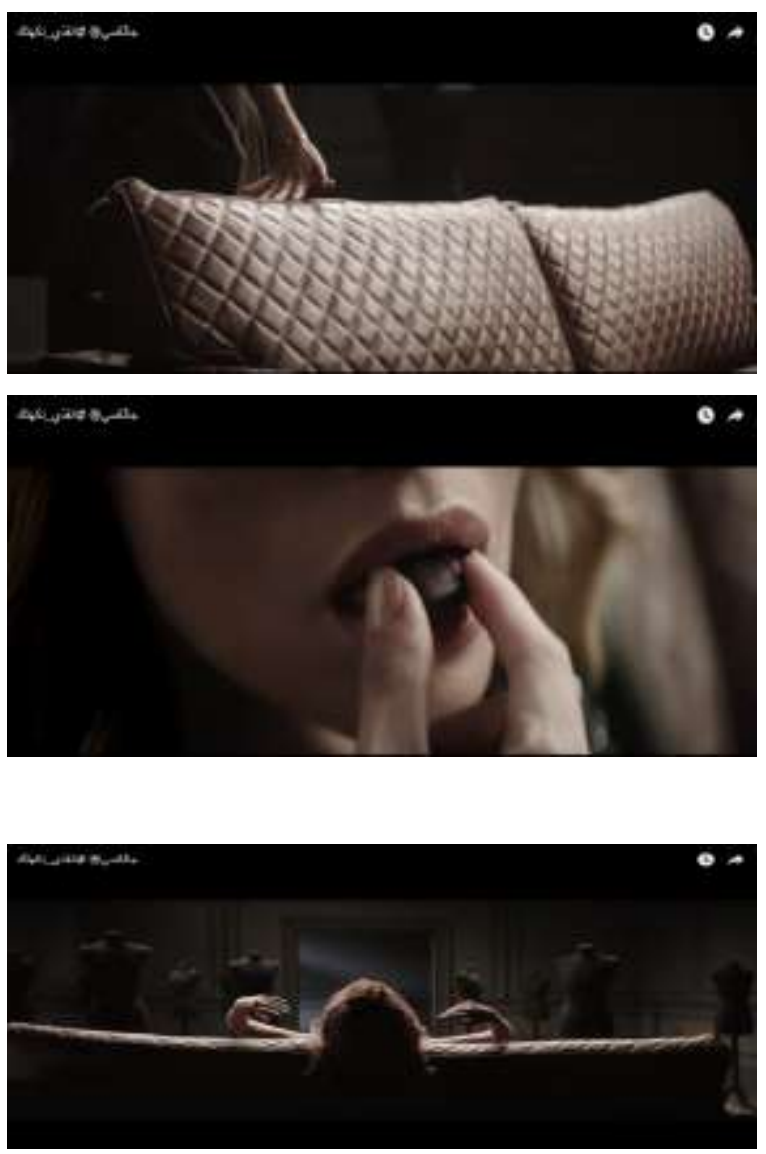

Feminine touch, as Goffman (1979) as cited in (Signoretti 2017) defines, is "females in advertising are frequently posing while using their fingers and hands to trace the outlines of an object, or to cradle it or to caress its surface" and this according to Signoretti "...encourages the idea that women are sexually available, weak, and vulnerable in relation to men" (pp.3,4). This idea of objectifying women according to the feminist ideas or subjectifying them according to postfeminism shows that women are used in both ways to fulfill an advertisement agenda. The advertisement's objective is attracting viewers so it uses the women to attract attention whether by showing the woman as vulnerable or as strong women. 
Another representation of women in advertisements is their roles in the society. Courtney and Lockeretz (46) as cited in (Tsichla $\&$ Zotos 2014) argue that in advertisements women are usually shown in domestic roles as housewives and as weak who is waiting for the man to protect her; this shows that the role of women is minute in the society and is dominated by men. This viewing women as domestic beings is used in patriarchal societies to indoctrinate little girls to grow up and become caretakers. These advertisements work as a way to educate women in accordance to the rules and norms of the society. Showing women and men in their stereotypical roles has its benefits for advertisers; Putrevu (2004) as cited in (Vantomme, Geuens \& Dewitte 2005) states that women and men interact well with those advertisements which depicts them in their expected roles in the society (p.4). This tells volumes of why advertisers do not abandon the use of stereotypes in their advertisements as they are reaping the benefits of these representations. However, this should not be a valid justification for directors; just because men and women react to something they were taught their whole lives does not mean it is the right way.

Furthermore, women in advertisements represented as weak and as one who are not capable of doing things without the guidance of men (Pillay 2010). This representation of women in advertisements as weak, as Pillay argues, is the reason why women do not get associated with occupations which require a lot of work and sweat like sport, mechanic, or any outdoor activity (2010: 28). This is very important because if women see athletic women or women mechanics they may believe in themselves more and attempt to do those occupations.

Regarding the representation of women in Kurdish media Dr. Muhammad, professor in media department at the University of Sulaymaniyah, says that:" There are currently a big number of women working in the different channels of media and they play a significant role in some parts too. We can say that women in the TVs are mostly working as news and entertainment program anchors. They are also working in the websites, radio channels, and print house too. In some cases, they even take the management roles of some of the media channels (2018).

So this gives hope that in Southern Kurdistan one can see women attaining is the highest position in media outlets and becoming managers. However, this may not be the case in reality as in Kurdistan we don't have women taking the management role of media channels. We have so many anchorwomen as they are brought on TV to be the face of the channel but the women do not take the important decisions. All the well-known TV channels are run by men like Rudaw, Kurdistan24 and NRTTV which are the most talked about channels in Southern Kurdistan. Dr. nazakat Hama Saeid, another professor in media department at the University of Sulaymaniyah, agrees with Dr. Muhammad. 
She agrees with Dr. Muhammad in that we have women working in media outlets and they work as anchors and sometimes correspondents and few in management. Dr. Hama Saeid says "There are women in media, but their position and roles are not up to the expectations. Their roles are mostly in news anchors, reception, sometimes as correspondents, but fewer in top management of the media channels" (2018).

With regard to the representation of women in Kurdish advertisements both Dr. Muhammad and Dr. Hama Saeid emphasizes that the roles of women are limited. Dr. Muhammad says that women are mostly shown in stereotypical roles and these roles would lessen the value of women in the society "Yes, the role of women in advertisement is limited, in most of the advertisements; women are portrayed as a housewives more than a woman with a significant role in the society" (2018). Dr. Hama Saeid on the other hand draws attention to another important point which is the exploitation of women in order to catch the attention of viewers "Women's role in the Kurdish advertisements just like most of the other advertisements are to draw the attentions only" (2018).

\subsubsection{Questionnaire analysis}

Questionnaire for this research paper was conducted so as to get information and data straight from advertisement directors in Southern Kurdistan. The reasons behind conducting this questionnaire were to know how Kurdish directors choose the women for their advertisements; what are the criterion for choosing actresses; to know if Kurdish directors use women for stereotypical roles or not. The questionnaire is divided into four parts; the first and second part are related to the personal information and work experience of the respondents which we deemed necessary to know some information about the directors in order to know who the forefront Kurdish directors are. The third part is about the state of directing work in Kurdistan and the Fourth part is about advertisement in Kurdistan and the role of women in them. Below is part by part analysis of the questionnaires.

\subsubsection{Personal Information}

The results show that all of the directors are male. This show how male-dominated this sector is in Kurdistan as we could not find any female directors.. The ages of the directors vary. All of the directors are between thirty and forty-five. This is important to notice as when there is no gender diversity then one would not get the perspective of women about directing in Kurdistan. This dominance by males in advertisement directing may be because of the belief that males are more talented and are more accurate in their job than woman as Smith, Pieper and Choueiti (2015) assert that "Female directors are perceived to make films for a subset and/or less significant portion of the marketplace. In contrast, films by males are perceived to reach wide and lucrative segments of the market" (p.4) so the companies may not put their trust on female directors. This lack of gender diversity in this important position in media is a direct reason why we see, in a feminist perspective, so many negative roles of 
women; Mills (1988) as cited in (Wood 1994)

states that if there were more gender diversity in director's position and other important positions there would be less negative portrayals of women. This statement by Mills may not be a fact as because of patriarchy women themselves are taught to conform to the norms of the society and patriarchy as Abrams and Harpham (2011: $89,91)$ argue and there is a chance that female directors may put women in the same roles as men do; however, this is an assumption as there is no valid data to back this claim.

\subsubsection{Work Experience}

The directors' experiences in media vary; one has twenty-two years of experience and all of the others have more than six years of experience each. Regarding directing advertisements, one has eighteen years of experience and most of the others have one to five years experience. The directors have worked in cinema, TV, animation, and communication. All the directors have stated that in their fields they have tried and use original ideas of their own; however, this is hard to believe since most the advertisements one sees on TV in southern Kurdistan one can find its original on YouTube and other foreign channels. For instance, for the advertisements about hair product and perfume you can go online and literally dozens of adverts of Arabic, Turkish and Indian origins with almost the same format. So this tells us a lot about how Kurdish directors are influenced by the surrounding countries and their ideas. What is meant by originality here is that the director would not copy and paste an advert and changes the actors only. Some people do say that Southern Kurdistan does have more freedom than the neighboring countries as Kaya (2016) state "...the long-term integration of international actors into the political-economic structure of theKurdish society and Iraqi Kurdistan's aspiration for statehood have led to Kurdistan being a better place to live as a woman compared to Iraq" (p.4) however this unoriginality of ideas in ad-making makes the level of freedom of women in Kurdistan irrelevant as the ideas that the directors get is not ideas coming from that freedom in Kurdistan. regarding the experience that the directors have, they collectively have a lot of years in experience but the fact that most of the advertisements are borrowed ideas from others tells us how directing in Kurdistan is not very advanced.

\subsubsection{Production Work in Kurdistan}

In the directors' answers about the question "What is the level of production work in Kurdistan?" 6 out of 8 directors said that it was good with 1 director saying it was average and 1 said it was bad. This is important to know as if the directors feel that advert production levels are high then it would indicate that every aspect of the production is on high levels including the employment of women actresses. However one could not see this high level that the directors talk about. Regarding the question "How much 
of the ideas that are turned into media production in Kurdistan are original and reflections of the Kurdish society?" the directors have unanimously said that the ideas are related to Kurdistan to some extent. This is true in the case of showing women as housewives and caretakers as the Kurdish society is still patriarchy "In a patriarchal society, for instance Kurdistan, the man is used to decide everything concerning his family" (Andersson 2003). However this is not true in the case of perfume and beauty advertisements as showing the body of a woman in a sexual way is not related to the Kurdish culture as religion does have its influence on culture and it doesn't allow these showcasing of women.

\subsubsection{Advertisement Industry and Role of} Women

By observing Kurdish adverts one can see how the adverts are repeated and copied from others. Nevertheless, there are some adverts that seem original and they involve comedians doing bits to both entertain the viewers and sell the products. The research has found that the directors' mentalities differ in regard to hiring for a role in their advertisements. As we asks "When selecting the actors of an advertisement production, how much is the gender (Male, Female) is important?" and 4 out of 8 respondants stated that the product itself chooses the gender. The 4 directors have stated different reasons for this; for instance, one of the directors stated that off course one should choose a female for a cleaning product and a male for production materials. This shows us how household chores are assigned to women and with no doubts whatsoever men have nothing to do with those chores. Sexton and Haberman as cited in Tsichla and Zotos (2014) explain that in patriarchy"...advertising imagery portrays females in housewife roles, situated inpredictable environments such as household settings..." (p.25) so this belief that women should be shown as housewives is related to the deep roots of patriarchy in any given society. Another director has sarcastically stated that the gender surely matters as one would not hire a female for a shaving-machine product. The question was:

When selecting the actors of an advertisement production, how much is the gender (Male, Female) is important?

[...] Very Important

[...] Important

[...] Not Important

[...] Changes as per the product, for example:

And the participant answered:

[...] Changes as per the product, for example: if you did an advertisement for a shaving-machine you wouldn't go and get a girl to do it

This answer tells us that in the mentality of the director there is only one use of women and adverts should not derive from that use and that use is beauty and elegance "...ads demonstrate females as sex objects, obsessed with beauty ideas and appearance" (Ali \& Shahwar 2011); since shaving-machine is related to hair and it is gross it cannot be attributed to the delicacy of 
women although women do shave their bodies and are in need of those machines.

The directors are all in harmony regarding whether the roles of women are limited or not; they have all ticked the limited slot. This limitation of roles is partially is the directors' fault as they are hardly giving women different roles. Also, the directors get famous actresses and use them in limited stereotype roles. the use of famous women is because they beautify themselves according to the latest trends and because of their beauty they would attract the most viewers as Dion, Berscheid, and Walster, (1972) as cited in Anurekha (2015) assert "what is beautiful is good" so the beauty of the actress equals the high quality of the product in the mind of the viewers.

Furthermore, the results have found that the directors say that they do not make discriminations based on the looks of the person auditioning. The directors state that they search for both looks and talent equally. By observing the advertisements that involve women one can only see women who possess some kind of beauty according to the beauty standards in Kurdistan. Anurekha (2015) argues that the beauty of the actress "...serves as a credibility factor to the brand". We have so many talented women but they do not feature in adverts as they are not attractive as they would show lack of credibility for the products. The body of the women matter as Richardson an Wearing (2014: 85) as cited in Rudloff (2016: 8) state that"...the female body has always been judged in terms of how it looks" so it does not matter whether a woman is talented or not, if she is not goodlooking then there is no chance for her to feature in an advertisement. According to this understanding one may forgive the directors as they are the victims of the products and the companies, too. If beauty heightens the credibility of a product then it is only normal that the companies would pressure the directors in order for them to choose attractive women.

Looking at these answers in a posrfeminist perspective then choosing women based on attractiveness is normal and should not be something that we would look at as bad. Genz (333) as cited in Adriaens and Van Bauwel (2014) says that in postfeminism sexy bodies and attractiveness are positive and these two features may be used to achieve changes within a society. Thus, this may be the argument of directors when talked to in length. They may argue that the reason for choosing beautiful women for their advertisements is to make the women in the society look up to them and try to be attractive themselves. In postfeminism consumerism is very important and is focused on besides style and fashion "Postfeminism emphasizes style and fashion" (Adriaens \& Van Bauwel 2014). So in postfeminism women are encouraged to buy clothes, shoes, handbags, and all the other products that help women show their sexiness and projecting that sexiness to the world. using famous women should be looked upon in a positive way as those women would promote the ideas of postfeminism in a perfect 
way as in Kurdistan those women are the epitome of fashion and style.

Regarding the reasons for the limitations of the roles of women in advertisements the directors are almost in agreement; they cite religion and the society as the main reasons for these limitations. Dr. Muhammad (2018) argues that one of the main obstacles that hinder the participation of women in advertisements is how the Kurdish society until now does not receive those women who work in the media well "Regarding the obstacles in terms of working in the media channels: a. Socially not accepting the role of women in the advertisement". One of the directors says that even men could not act in certain advertisements like bathing. But this is not true as there is a very famous advertisement nowadays in Kurdistan which is about showering tools that show half of the man's body naked and no one bats an eye.

Dr. Muhammad provokes two other important reasons; first he argues that there is a lack of awareness regarding the role of women in media in Kurdistan; second, he asserts that harassment makes it difficult for women to have an important role in the Kurdish society. These two reasons are related to one another as harassment happens because individuals lack awareness (Carr et al. 2000). There is a very negative idea in Kurdistan about women who work in media; people vie those women working in media as open and promiscuous women. This negative idea definitely affects women and makes them hesitate before entering the field. The harassments happen as women get bombarded with messages and in many cases people go to them in public and disturb their privacy. Also, many times we hear that those working women get offered higher salaries and positions in return for some sex activity with high-ranked officials. Besides, in Kurdistan we do not have a law that prevents harassments in the work places so the women have to endure men and their advances in order for them to keep their jobs.

\section{Conclusion}

This research examined the on/off screen portrayal of women through Kurdish advertisement through three aspects of Kurdish media ads. Within the 'On-screen portrayal' realm it focuses on the variety of stereotypical depiction of women, in particular for its engagements of sexual difference, sexual/gender identity, or sexual politics. As it concludes that depicting women as weak and reliable on men. All the Ads products in Kurdish television depict women as they cannot do anything without support of men. They have to be taught by men on how to do everyday tasks. The second it studies gender issues and stereotyping women societal role as housewives, as they have always been. In addition, to issues of hypersexualizaton and objectification of women as many advertisements as a tool to attract viewers through presenting them in provocative outfits and acts. Lastly interrogates the 'Off-screen representation' of women, in ads industry or apparatus of media productions and the position of women. 
This research concluded that the media industry is a heavily male dominated and mostly female exclusion. This research recommends more theoretical contributions and other media major theories such as Media apparatus and ideology, as well as onloff-screen theories in the media outlets. Even more surprisingly, the advertisement industry is also dominated by males. Among the eight advertisements data sample of this research not a single one is woman. The exclusion of female from media productions as it has been explained through this research not a single female is among those who working in the advertisement production industry as a director. The fact that advertisement industry is dominated by males has an ongoing effect on the way women are portrayed. The same mentality that has drawn the image of a woman as a submissive housewife is still enjoying the same power as before to reinforce the same image.

This research proved that advertisements cannot be produced outside of the cultural context in which the advertisement is produced. It cannot even bypass the cultural boundaries of the target market to which the advertisement is produced to. Hence, women have very limited space in advertisements to play their role in. A clear example would be an advertisement for a hair shampoo. Even if a woman actress is ready to play a role of a woman washing her hair under the shower, she still cannot do it because of these boundaries. We can conclude that culture and religion can play a very important role on the way women are participating in advertisements.

Another discovery of this research is that even the professionals working in media industry have the mentality of male dominance. Through questionnaires, one can conclude that they are unconsciously emphasizing the same prototype of women. They have emphasized on the importance of considering culture when determining a role to a woman in advertisements.

Finally, since advertisement can be seen by a large number of people in the society, it can be concluded that it is an important tool that can be used to change the public perception of women. for instance, instead of delivering a message that washing clothes is the responsibility of a woman alone by showing a woman washing clothes while advertising for a detergent, it can show the function of washing clothes as one of the whole family by showing both the man and the woman. Advertisement is a two-sided tool to reinforce the same weak image of women, and another side is that it can be an instrument to change the perception of the society about women.

\section{$\underline{\text { References }}$}

- Abrams, M.H. and Harpham, G., 2011. A glossary of literary terms. Cengage Learning.

- $\quad$ Adriaens, F. and Van Bauwel, S., 2014. Sex and the city: A postfeminist point of view? Or how popular culture functions as a channel for feminist discourse. The 
Journal of Popular Culture, 47(1), pp.174-195.

- Ali, S. and Shahwar, D., 2011. Men, women and TV Ads: The representation of men and women in the advertisements of Pakistani electronic media. Journal of media and communication studies, 3(4), p.151.

- Baxandall, R. and Gordon, L., 2002. Second-wave feminism. A companion to American women's history, pp.414-432.

- $\quad$ Bisong, P.B. and Ekanem, S.A., 2014.A critique of feminism. Am. J. Soc. Mgmt. Sci, 5(2), pp.33-38.

- Bruinessen, M.V., 2001. From Adela Khanum to Leyla Zana: women as political leaders in Kurdish history. Women of a Non-state Nation: The Kurd, pp.95-112.

- Bryson, V., 2016. Feminist political theory. Palgrave Macmillan.

- Dean, J., 2009. Who's afraid of third wave feminism? On the uses of the 'third wave'in British feminist politics. International Feminist Journal of Politics, 11(3), pp.334-352.

- Elo, S. and Kyngäs, H., 2008.The qualitative content analysis process. Journal of advanced nursing, 62(1), pp.107-115.

- Fateh, N., 2012. Honour Killing (Doctoral dissertation).
- Freedman, J., 2001. Concepts in the social sciences: Feminism. Open UniversityPress, Philadelphia.

- Gill, R., 2007. Postfeminist media culture: Elements of a sensibility. European journal of cultural studies, 10(2), pp.147-166.

- Hama Saeid, N., 07/05/2018

- Hooks, B., 2000. Feminism is for everybody: Passionate politics. Pluto Press.

- http://www.qualitativeresearch.net/index.php/fqs/article/viewF ile/175/392... (Accessed 10 August 2014).

- Human Rights Commission, 2005. Muslim Women, Dress Codes and Human Rights: An Introduction to Some of the Issues. Human Rights Commission.

- Kaya, Z.N., 2016. Women in postconflict Iraqi Kurdistan. Open Democracy.

- Kidd, 2015. Representation.Routledge.

- Lewis, P., 2014. Postfeminism, femininities and organization studies: Exploring a new agenda. Organization Studies, 35(12), pp.1845-1866.

- Lorber, J., 2001. Gender inequality. Los Angeles, CA: Roxbury.

- Malson, H., Halliwell, E., Tischner, I. and Rúdólfsdóttir, A., 2011. Postfeminist advertising laid bare: Young 
women's talk about the sexually agentic woman of 'midriff'advertising. Feminism \& Psychology, 21(1), pp.7499.

- Mason, J. (2002) Qualitative Researching(2nd edn). London: SAGE publications.

- Miller, G., 2008. Women's suffrage, political responsiveness, and child survival in American history. The Quarterly Journal of Economics, 123(3), pp.1287-1327.

- Moran, R.F., 2004. How second-wave feminism forgot the single woman. Hofstra L. Rev., 33, p.223.

- Muhammad, S., 06/05/2018

- Murphy, P.F. ed., 2004. Feminism and masculinities. Oxford University Press on Demand.

- Murray, N. \& Hughes, G. (2008) Writing up Your University Assignments and Research Projects: a Practical Handbook. Berkshire: Open University press.

- Nagi, P., 2014. Projection of women in advertisement: A gender perception study. International Journal of Managerial studies and research, 2(9), pp.75-88.

- Page, S., 2006. Feminism and the third wave: politicising the sociology of religion?. Comunicaciónpresentada en la University of Leeds, UK, e-paper, (17).
- Paglia, C., 2008. Feminism past and present: Ideology, action, and reform. Arion: A Journal of Humanities and the Classics, 16(1), pp.1-18.

- Pillay, N., 2010. The protrayal of women in television advertisements on SABC3: a reflection on stereotypical representation (Doctoral dissertation).

- Qasim, N., Mehboob, S., Akram, Z. and Masrour, H., 2015. Women's Liberation: The Effects of Patriarchal Oppression on Women's Mind. International Journal of Asian Social Science, 5(7), pp.382-393.

- Rivers, N., $2017 . \quad$ Between 'Postfeminism (s)': Announcing the Arrival of Fourth Wave. In Postfeminism (s) and the Arrival of the Fourth Wave (pp. 7-28). Palgrave Macmillan, Cham.

- Robson, B., 1996. Iraqi Kurds.Their History and Culture.CAL Refugee Fact Sheet Series No. 13.

- Robson, C. (2011) Real World Research (3rd edn).Chichester: John Wiley \& Sons.

- Schreier, M. (2012) Qualitative Content Analysis in Practice. London: SAGE publications.

- $\quad$ Signoretti, N., 2017, November.A Study of Gender Advertisements.A Statistical Measuring of the Prevalence of Genders' Patterns in the Images of Print Advertisements.In Multidisciplinary 
Digital Publishing Institute Proceedings

(Vol. 1, No. 9, p. 947).

- Snodgrass, C., 2013. THE “ANGEL IN THE HOUSE".

- $\quad$ Sun, Z., 2017. Exploiting Femininity in a Patriarchal Postfeminist Way: A Visual Content Analysis of Macau's Tourism Ads. International Journal of Communication, 11, p.23.

- Tsichla, E. and Zotos, Y., 2014. Female portrayals in advertising past research, new directions.

- van Pelt, J.C., 2016. Individualized Entrepreneurial Power Women: Examining gender inequality in the business world through the lens of postfeminism's emphasis on individualism, choice and empowerment (Master's thesis).

- Vantomme, D., Geuens, M. and Dewitte, S., 2005. How to portray men and women in advertisements? Explicit and implicit evaluations of ads depicting different gender roles.

- Walby, S., 1989.Theorising patriarchy. Sociology, 23(2), pp.213-234.

- Walford, G. (2005) 'Research Ethical Guidelines and Anonymity', International Journal of Research and Method in Education, 28(1): pp. 83-93.

- Walker, A., 2015. Interrogating the Relationship of Postfeminism and Neoliberalism in Orange is the New
Black(Doctoral dissertation, University of Huddersfield).

- Wood, J.T., 1994. Gendered media: The influence of media on views of gender. Gendered lives: Communication, gender and culture, pp.231-244.

- World Health Organization, 2008. Eliminating female genital mutilation: an interagency statement-OHCHR, UNAIDS, UNDP, UNECA, UNESCO, UNFPA, UNHCR, UNICEF, UNIFEM, WHO.

- Yeşil, S., 2003. Unfolding Republican Patriarchy: the Case of Young Kurdish Women at the Girls Vocational Boarding School in Elazig (Doctoral dissertation, METU).

- Zheng, J., 2016. New Feminism in China: Young Middle-class Chinese Women in Shanghai. Springer. 